\title{
1. Assessing economic law under crisis - a framework of analysis
}

\section{Harri Kalimo and Max S. Jansson ${ }^{1}$}

\subsection{BACKGROUND}

The second term of the European Commission President Jose Manuel Barroso coincided with the most severe economic crisis in the Union's history. What started as a credit crunch and sovereign debt crisis grew into a litmus test on the entire European Union. While it still too early to tell if the Union weathered the crisis, one thing appears certain: the unique circumstances have led to myriads of intriguing developments and, subsequently, lively scholarly activity to analyse and explain them. The intention of this edited volume is to contribute to the debate.

First of all, we propose to approach the topic from a specific institutional viewpoint: that of the Barroso II Commission. It is important to state from the outset that our intention is not to give an authoritative judgment on whether the policy choices during the crisis have been 'right' or 'wrong'. Both the scale and normative tone of such an approach push it beyond our competences and intentions. Rather, our objective is more modest; to critically analyse whether and how EU economic law developed during the Barroso II Commission, taking as a premise the Commission's central, supra-nationalist (that is integrationist) position in the EU's institutional framework.

Second, the impacts of the crisis were felt in the EU's overarching legal framework. This is particularly true for economic law because of its obvious close interrelationships with the distressed economy. Rules on various aspects of the economy are likely to be root causes for and/or essential tools out of the crises. By economic law, however, we do not

1 The research of the authors for this edited volume was conducted within the framework of Project eCoherence, financed by the Academy of Finland. The authors are grateful to Viivi Järvi, Filip Sedefov and Fausta Todhe for their valuable assistance in the preparation of the book. 
only mean the legal provisions that determine the EU's macro-economic monetary and fiscal policies, which have understandably dominated the discourse so far. Our intention is to expand such analysis to a selection of five specific areas of economic law and to scrutinize the track-record of the Barroso Commission in developing these areas further under the crisis. Our assumption is that crises offer unique opportunities for change: 'never waste a good crisis'.

Our choice of the selected areas of economic law is based on a number of criteria. The areas are first of all fundamental to Europe's declared strategy out of the crisis. The importance of understanding and addressing the root causes of the banking and sovereign debt crises is obvious. Chapters 2 to 5 therefore frame the debate by insights on European economic and monetary policy at the epicentre of the crisis. By investigating the financial markets and Social Europe, it is also possible to weld the internal market and economic policy narratives together.

The EU's vision as outlined in the Europe 2020 strategy is even broader than this, however. It necessitates an open economy that also enables reaping full benefits from procurement by public authorities. With an impressive 15-20 per cent of the GDP, this area seems particularly prone to protectionist pressures during a crisis both inside the EU (Chapter 6) and on the global market place (Chapter 7). Next to managed spending, crisis economies can also be balanced by solid revenues. Taxation in general, and value added tax specifically, are the source of up to 10 per cent of the EU's GDP. A careful analysis (Chapters 8 and 9) on the attempts to clarify the legal frameworks and to tighten rules around (value added) tax evasion and fraud seems very appropriate to our investigation across key areas of EU economic law. Finally, intellectual property rights have maintained a prominent role in the Barroso II Commission's pledges towards the Europe 2020 target of an innovative, knowledge-based growth economy. Chapters 10 and 11 hence explore whether the crisis has affected, for the better or for the worse, the development of the legal frameworks that regulate an alleged 40 per cent of the total economic activity in the EU.

The second reason behind our selection of these areas of EU economic law is that they represent three constitutionally distinct spheres of law: areas where the Lisbon Treaty confers competences exclusively on the Union (monetary policy), those where the competences are shared between the Union and the Member States (economic policy, financial services, public procurement, intellectual property rights (IPRs) and value added taxation (VAT)), and finally those where the competences remain primarily on the Member State level (fiscal policy and taxation other than VAT). EU economic law can in this way be used as a case 
study for examining the development of integration across areas of different competences. Taking into account our institutionalist focus on the Commission, the diversity in the choice could thus lead to variance on the role of that central institution in developing EU economic law. A further crucial spin to such constitutionalist analysis is that recent literature tends to perceive the crisis as leading to changes, but changes of particularly inter-governmentalist emphasis. In other words, the changes have been seen to take place outside of the constitutional core of EU law as treaties between the Member States, not through the supranationalist Community method. Will our constitutionally distinct areas of analysis confirm or challenge such assumptions on European integration?

To summarize, this book thus investigates five central policy areas economic and monetary policy, internal market, public procurement, taxation and IPRs - in order to provide an instructive overview of the development of economic law during the Barroso II Commission. Having determined the areas of economic law that we intend to research, and having established an analytical framework with parallel institutionalist and constitutionalist angles, we can next in Section 1.2 elaborate in more detail the questions that the contributions to this volume jointly address. We shall then in Section 1.3 finish this Introduction by a preliminary outline of the specific substantive law issues that each of the chapters will cover.

\subsection{CENTRAL THEMES}

The specific themes of this book are the outcome of a preliminary analysis, organized in the form of a series of lectures at the Institute for European Studies of the Vrije Universiteit Brussel. The editors identified, in collaboration with the lecturers, a number of themes that seemed to cut across the lectures on EU economic law in time of economic crisis. This preliminary research was then followed up by a more detailed analysis of four of the themes up until summer 2015.

The first research theme that each one of the contributors to this volume has sought to address is the extent to and manner in which the Barroso II Commission was, using the stimulus or even the sheer coercive force of the economic crises, able to incite policy change in the area of law in question. A case study approach in a number of parallel areas of law allows us to illustrate in concrete terms the changes that did (or did not) take place. The idea is to use the extensive experience of our authors in choosing those paradigmatic examples that offer the most useful insights into the potential deepening, stagnation or crumbling of 
European integration. The book in other words zooms in on the constitutional balance between centralization and fragmentation in this area, which has from the outset formed the core of the European Union. Has the crisis, due to the inherent political controversy and more inward looking politics, perhaps ground the development of common European economic law to a halt, or even led to its retreat? Has it paused further centralizing tendencies and served as testimony that the uniformity of the legal frameworks has now reached its limits? Or has further integration in European economic law rather been the solution that the Barroso II Commission has advocated to give further impetus to European societies, and hence to assist in solving the current crisis? Perhaps the unprecedented circumstances have opened possibilities for extraordinary actions, integrationist measures that during prosperous times would have been unthinkable? Our first theme thus is about the on-going debate on the limits of European integration, a debate which the Eurozone crisis seems to have accentuated. ${ }^{2}$

The second theme that the chapters set out to investigate is the impact of the crisis on the institutional landscape within EU economic law: are there noteworthy changes in the inter-institutional relations or in the organizational environment in which the Barroso II operated? Institutional changes obviously link to the constitutional narrative because they may implicate shifts from the harmonizing Community method towards inter-governmentalist approaches or even a devolution of decisionmaking to the Member State level, as will be observed.

The crisis may also have heightened the debate about the nature of European integration, about l'Europe Social. Our third analytical theme thus adds to the narrative the neo-functionalist twist of spill-overs between policy fields: have non-economic social challenges received more or less attention in the scrutinized areas of economic law due to the crisis? One could during economic distress predict, for example, spillovers from the classic, more narrowly defined objectives of open markets and free competition to considerations of social security and unemployment. One might also observe an increase in the prevalence of noneconomic objectives in that conflicts in law between the pursued economic and non-economic values accentuate. The outcomes of the conflicts may not favour the non-economic rights, however. In the views of some commentators the EUCJ's famous decisions in the Viking and

2 Christian Schweiger and José M. Magone, 'Differentiated Integration and Cleavage in the EU Under Crisis Conditions' (2014) 15 Perspectives on European Politics and Society 259. 
Laval cases, for example, increasingly subordinate the social rights of collective bargaining to the 'superior objective' of competition within the internal market. ${ }^{3}$ Can such trends be detected within the selected areas of economic law?

The final, fourth theme to be addressed in this book is the Union's international position in economic law during the crisis. Considering the trans-Atlantic roots of the crisis, as well as the global nature of the economy, it seems important for the edited volume to investigate also the international aspects of the Barroso II Commission's activities during the crisis. Did the Commission, for example, forge closer collaboration with third countries or rather seek to strengthen the EU's international position in specific areas of economic law?

\subsection{OUTLINE}

The authors of this edited volume combine expertise of a cross-cutting nature. Insider insights to the activities of the Barroso II Commission are first of all offered by leading in-house experts from Commission Directorate-Generals in charge of the analysed fields: Economic and Financial Affairs (Taneli Lahti), Internal Market (Jonathan Faull) and Procurement (Frank Hoffmeister). This expertise is complemented in tax issues by a specialist (Andreas Strub) from the Council of the EU. Public sector expertise is mixed with selected private sector perspectives in areas crucial to the European companies and their competitiveness - procurement (Maarten Meulenbelt, law practitioner), value-added taxation (Ine Lejeune, consultant) and intellectual property rights (Kaisa Olkkonen and Jari Vaario, corporate). Finally, the insiders' perspectives are complemented by external observations from the media (Jan Strupczewski from Reuters) and academia (Christophe Geiger, Max S. Jansson, Harri Kalimo and Janne Salminen).

The book begins with four chapters (2 to 5) that together in Part I set the scene by describing developments in the EMU and the European

3 See e.g. Eftychia Achtsioglou and Michael Doherty, 'There Must Be Some Way Out of Here: The Crisis, Labour Rights and Member States in the Eye of the Storm' (2014) 20 European Law Journal 219; Catherine Barnard, EU Employment Law (4th edn, Oxford University Press 2012) 205; Brian Bercusson, Collective Action and Economic Freedoms before the European Court of Justice (European Trade Union Institute 2007); Eleanor Spaventa, 'From Gebhard to Carpenter: Towards a (Non)-Economic European Constitution' (2004) 41 CMLR 743. 
internal market. In Part II, the analyses then drill deeper into the impacts of the crisis on three core areas of European economic law: public procurement (6 and 7), taxation (8 and 9) and IPRs (10 and 11). The concluding Chapter 12 will in Part III bring the narrative back to our four cross-cutting research themes: the effects of the crisis on harmonization, institutions, non-economic values and international actions.

Part I, 'Setting the Scene', starts with Chapter 2 by Reuters long-time EU economic and monetary affairs correspondent Jan Strupczewski. Strupczewski has been observing the unfolding of the crisis from close since its inception. He highlights the key developments in the European economic and monetary policy during the past years and thereby frames the forthcoming analyses on how the crisis during the Barroso II Commission has affected key areas of EU economic law. He claims that the time during the Barroso II Commission has been crucial to the way Europe is now organized and how it will do business in the future. Many European policy-makers believe that the EU only changes when there is no other choice and that it does so at the very last minute. And it is true, argues Strupczewski. The analysis outlines the four main things that the EU did to deal with the crisis, in particular how it made national governments take seriously their own commitments and cede more of their sovereignty in economic policy making and financial supervision to the EU level. The chapter further explains how the Commission managed to sharpen existing laws and initiated new treaties. New institutions such as the European Stability Mechanism were created, and all this was backed up with sufficient financial clout. The EU and the euro zone have come out of the experience stronger and better equipped for the future. The transfer of more national powers to the European level would have never happened were it not for the crisis. The chapter finishes by assessing the fundamental issues that are left on the table for the Juncker Commission to come to grips with: the lack of trust between the EU's banks and their aversion to lend to each other and the real economy: the euro zone companies and individuals. Just how much further will the next Commission need to, and be able to proceed?

Building on the previous chapter's critical overview of the developments in the EMU, Taneli Lahti - economist in the Cabinet to the Commission Vice President Rehn - unveils in Chapter 3 how the crisis unfolded from the perspective of a Barroso II Commission insider. Lahti reminds us of the severe macro-economical imbalances that had, despite the warnings also from the Commission, built up in the European economy by the beginning of Barroso's second term. Subsequent measures taken by the Commission were a combination of efforts to simplify and coordinate the policy processes, and to supervise and enforce 
Member State actions. The Commission focused on ensuring that the Member States respected the rules they had set for themselves, because the negative consequences of deviations quickly spread across the European economies. While the EU has indeed taken quantum leaps in the effective practical integration of the economic and monetary union, Lahti argues that the problems extend beyond public finances to more structural challenges. The chapter concludes by contemplating the realms of legitimacy in European politics: European citizens currently seem to have limited appetite to proceed on the path of European integration towards for example the collection and spending of revenues at the European level. Even the current framework remains contested.

While the economic, financial, and sovereign debt crises led to a major overhaul of the EU's and EMU's economic governance, they also had profound implications on the EU's internal market. Benefitting from the unique vantage point of Director-General Jonathan Faull, Chapter 4 investigates how during the economic crisis the Barroso II Commission affected the internal market for financial services in boosting Europe's competitiveness. The Commission strove to ensure that investments were financed and brought about the sustainable growth and employment that Lahti was calling for in his chapter. The chapter also points out that the crisis offered the Barroso Commission an opportunity in re-structuring the roles and relationships between various actors - such as creditors, shareholders and taxpayers. Such changes would arguably make the European financial markets more effective and legitimate. This quest for legitimacy seems important because, as Professor Faull argues, the Member States also need to face the social challenges that the economic turmoil accentuates. Very high unemployment and other long-term social issues such as ageing populations, increased immigration and the distribution of social benefits to non-nationals are examples of European challenges. Simultaneously, diversity seems to be increasing on numerous fronts. The role of the internal market thus seems fundamental in providing stability for a prosperous European future.

Chapter 5 by Janne Salminen finishes the scene-setting Part I. Salminen, Senior Lecturer in law at the University of Turku, merges and builds upon the EMU and internal market analyses of Strupczewski, Lahti and Faull. He engages in a concise legal analysis of the changes that the economic crisis triggered in the EMU and the internal market. Salminen shows how the crisis has been handled in many different ways, which illustrates the astounding ability of the EU's legal framework to react to crises, often even without revising the Treaties. The law on economic and fiscal coordination as amended stretches however the constitutional limits of the Treaties. The legal bases provided by the 
Lisbon Treaty are completely exhausted, and where they are no longer capable of offering the prerequisite legal basis, international agreements are used as the legal framework instead. This technique is evident both in the field of stabilization mechanisms and in the field of economic and fiscal governance. These developments lead in Salminen's view nonetheless to issues of constitutionality, transparency and clarity. Institutionally speaking, the European Parliament's limited role is problematic, while the Council and the European Council have taken a central role at the European Union level in actively seeking solutions to the crisis. Undoubtedly, the new means of economic and fiscal governance that the crisis has triggered have also strengthened the powers of the European executive, the Commission. The role of the European Central Bank has also been growing, sometimes in somewhat unconventional ways.

Having set the scene, the analysis moves then to public procurement as the first specific area of economic law under exploration in Part II. Maarten Meulenbelt, Partner in charge of public procurement in a leading Brussels law firm Sidley LLP, explains in Chapter 6 how the development of open and well-functioning competition between companies during the public purchasing processes aims at reducing prices and guaranteeing better services for Europe's citizens. While discriminatory technical standards have been removed and the protection of bidders improved over the years, the Barroso II Commission engaged in what may be described as the fourth major modernization of the EU's public procurement rules. The scope of the rules have been expanded by encouraging procurement to achieve wider policy goals, including innovation, employment, environmental protection, and sustainable production (with some extraterritorial effects). During the times of an economic down-turn, however, such expansions seem to merit particular vigilance. The risk of national policies with wider policy goals being used for protectionist purposes appears evident. The national governments are under pressure to spend taxpayers' money in a way that benefits local companies and local labour. The questions do not limit themselves to intra-EU situations, but expand also to the EU's international trade relations. While attempting to improve the market access of EU companies to third countries in the context of the WTO's Agreement on Government Procurement (GPA), three EU directives permit or encourage preference for bids from within the $\mathrm{EU}$ - an issue meriting further attention as outlined in the following chapter.

Chapter 7 by Frank Hoffmeister, who acted as the Deputy Chef de Cabinet of Trade Commissioner De Gucht in the Barroso II Commission, expands the analysis on the international aspects of EU's public procurement law. The investigation starts off with the draft regulation on the 
position of third-country bidders in the EU internal procurement market, which the Barroso II Commission proposed in April 2013. The chapter will elaborate the central 'reciprocity' rationale of this instrument. The review includes an institutional dimension as it provides an assessment of the positions of the European Parliament and the Council, and the ensuing inter-institutional controversies. The analysis is further linked to the on-going efforts of the European Commission on international fora to negotiate public procurement chapters in free trade agreements with third countries. Combined, the steps in the chapter will allow for a critical analysis on whether and how the reform of public procurement rules has been affected by the economic crisis and used as a way to come out of it.

European tax policy and law, a central realm of unanimity decisionmaking in the Council also after the Lisbon Treaty, has traditionally developed slowly. Andreas Strub, Head of Unit for Tax Policy, Export Credits and Regional Policy in the Council of the European Union explains in Chapter 8 however that a clear shift in EU tax policy may be observed in the developments during the Barroso II Commission. The importance of improving also the revenue side of the cash-constrained national budgets has become evident as a consequence of the crisis. Taxation has clearly gained in importance, and the range of issues covered has increased to promote growth and competitiveness alongside other EU policies. Strub's chapter aims at illustrating the areas of EU tax law where progress was made during the Barroso II Commission and at explaining what made the new dynamics in the field possible. The chapter further elaborates how these developments have created new dimensions of tax law and policy both in the EU and at the highest level of international collaboration.

Value added tax remains the single most important source of state finance in many European economies. Focusing on consumption, it is also a type of tax that is less detrimental to growth, which is essential for the EU's strategy to exit the crisis. ${ }^{4}$ Despite its enormous upside potential - in particular during times of economic hardship - the collection of VAT in the EU is not maximized: only 52 per cent of consumption is taxed. Ine Lejeune, partner in charge of Tax Policy, dispute resolution and litigation at Law Square, scrutinizes in Chapter 9 how the Barroso Commission has with its VAT Strategy been addressing the three principal causes of the increasing VAT gap: non-compliance due to overly

4 Directorate-General for Economic and Financial Affairs of the European Commission, 'Tax Reforms in EU Member States 2014: Tax Policy Challenges for Economic Growth and Fiscal Sustainability' (2014) 6 European Economy 12. 
complex VAT legislation, differences in the tax authorities' and taxpayers' interpretations of the law and, most importantly, criminal fraud. The chapter includes analyses of the Barroso Commission's announced efforts in re-designing the EU VAT system by broadening the base, by reducing the costs of enforcement and compliance as well as by removing 'the red tape' for the parties collecting the taxes, the businesses. Have the Commission's efforts been effective, and have they been hampered or promoted by the economic crisis? The analysis also touches upon the development of the EU's global collaboration on VAT, such as the interactions with the OECD. Finally, the chapter finishes off by highlighting a number of crucial VAT issues, where much could still be achieved by the upcoming Juncker Commission in leading the EU definitively out of the crisis.

Christophe Geiger, Director of the Centre for International Intellectual Property Studies (CEIPI), University of Strasbourg, gives an academic's perspective to the analysis in Chapter 10. Well-functioning intellectual property rights (IPRs) are a necessity for promoting innovation and growth in Europe's way out of the crisis. IPR-intensive industries generate approximately 40 per cent of total economic activity in the EU. Besides affecting the European economy, the EU puts high hopes in IP in order to ensure food security, address climate change, deal with demographic change, improve the health of citizens and play an essential role in fostering cultural diversity. This chapter assesses the challenge that the Barroso II Commission was faced with in fostering the development of a growth and competitiveness oriented framework for intellectual property (IP), while fully balancing the interests of all stakeholders and values more generally speaking. The analysis reveals how striking a balance can prove challenging. The EU's IP system is a dearth of coherence, and in many respects still an incomplete construction. The recent failure of the Anti-Counterfeiting Trade Agreement (ACTA) goes to show that a consensus on the right balance between IPRs and fundamental rights is never easily achieved, in particular when it is sought at the level of international cooperation. The chapter concludes that paradoxically, the more important intellectual property rights have become to the crisisstruck EU economy, the more they are contested. Having outlined the developments in the construction of the intellectual property regime at EU level, the chapter briefly draws perspectives on how to secure the establishment for the future of an EU IP system which would better combine innovation and societal concerns.

Chapter 11 of the book completes the exploration of specific areas of the EU's economic law during the Barroso II Commission by offering 
insights into European intellectual property rights policies. Kaisa Olkkonen and Jari Vaario, senior corporate figures with years of firsthand experience on IPRs, with Professor Harri Kalimo, Institute for European Studies (IES) at the Vrije Universiteit Brussel, offer three fundamental examples from the area: standard essential patents (SEPs), copyright licensing for content online and copyright levies for digital copies. The chapter's conclusions are somewhat negative, however: the authors assess that during the Barroso II Commission, the development of the EU's IPR policies seems to have been sluggish, and in parts even counter-productive from the perspective of Europe's commercial interests. The crisis has given the Commission only limited leverage in persuading the Member States to push the digital agenda. The Member States seem to have become even more defensive. While the Commission may have managed to put some of the issues on the agenda, the time it took to do this entails a heavy penalty on the European market players and consumers. In the area of copyright licensing, the delay has also meant a non-economic loss on cultural diversity. Much work remains to be completed by the Juncker Commission, and constitutionally speaking the slow process at EU level has in some cases moved the frontier of policy developments to the national level.

In the concluding Part III, the editors to this volume (Harri Kalimo and Max S. Jansson, also from the IES (VUB)) add a final layer of analysis on the basis of the area-specific enquiries of the preceding chapters. The conclusions in Chapter 12 are framed against the book's four, interwoven themes: they provide insights on the differences and commonalities in the areas of law in terms of further integration, changes in the institutional landscape, and the prevalence of non-economic considerations, as well as the international position of the European Union.

The analysis reveals that a large part of the achievements of the crisis have indeed been about completing the EMU and the internal market for financial services, where actions were also most urgently needed. Progress in taxation has been broad, albeit not so profound nor fully comprehensive, leaving counter-intuitively more to be desired in indirect VAT rather than in direct taxation. In public procurement and intellectual property rights the development has varied, respectively, from slow to sluggish and even counterproductive. Kalimo and Jansson find the differences across the fields of economic law noteworthy, because the core of the crisis has gradually shifted towards the real economy; growth, competitiveness and investments. This calls for the Juncker Commission to focus on public procurement and intellectual property rights, which are essential in supporting progress on all three fronts. Across all the studied fields, Kalimo and Jansson conclude that the means of integration are 
more and more differentiated, while policy developments are becoming increasingly entangled with constitutional questions.

Overall, the crisis, by focusing the attention of the Barroso Commission too exclusively on the most urgent problems, failed to incite breakthroughs in fundamental policies, and to push past inter-institutional impasses and interest captures of longer-term nature. Part of the conundrum is to find the nuanced and legitimate processes through which the economic and non-economic (social) considerations may be appropriately reconciled. Time may be running out; problems risk turning structural and the competition escaping for good, while the external politicomilitary circumstances appear increasingly turbulent. So while certainly not wasted, the book concludes that the economic crisis has not been optimally exploited for the development of EU economic law, either. 